Jurnal Sain Veteriner, Vol. 37. No. 1. Juni 2019, Hal. 34-40

DOI : $10.22146 /$ jsv.34037

ISSN 0126-0421 (Print), ISSN 2407-3733 (Online)

Tersedia online di https://jurnal.ugm.ac.id/jsv

\title{
Pengaruh Pemberian Serum Albumin Manusia terhadap Kadar Albumin dalam Darah pada Anjing dengan status Hipoalbuminemia
}

\author{
The Effect of Human Serum Albumin Application to \\ Albumin Blood Level in Hypoalbuminemia Dogs
}

\author{
Julita Dewitri Merthayasa ${ }^{1}$, Putu Devi Jayanti ${ }^{1}$, Soedarmanto Indarjulianto ${ }^{3}$, Ryan Hadi Permana ${ }^{4}$, \\ Nadia Liswardani Destinanda ${ }^{4}$ Agustina Dwi Wijayanti ${ }^{2 *}$ \\ ${ }^{1}$ Sain Veteriner, Fakultas Kedokteran Hewan, Universitas Gadjah Mada \\ ${ }^{2}$ Departemen Farmakologi, Fakultas Kedokteran Hewan, Universitas Gadjah Mada \\ ${ }^{3}$ Departemen Ilmu Penyakit Dalam, Fakultas Kedokteran Hewan, Universitas Gadjah Mada \\ ${ }^{4}$ Fakultas Kedokteran Hewan, Universitas Gadjah Mada \\ Fakultas Kedokteran Hewan Universitas Gadjah Mada, Jalan Fauna No.2, Karangmalang, \\ Yogyakarta 55281, Telp: (0274) 560861, 560862 Fax: (0274) 560861 \\ *Email: tinabdy@ugm.ac.id
}

Naskah diterima : 9 Maret 2018, direvisi : 23 Januari 2019, disetujui : 30 Januari 2019

\begin{abstract}
Albumin consists of $50 \%$ of the total plasma protein and it is very important protein in the animal's body. Hypoalbuminemia can occurs due to various conditions, such as loss of protein nephropathy, loss of enteropathic proteins, chronic and acute diarrhea or heavy bleeding as well as malnutrition and malabsorption conditions. This study aims to determine the effect of human serum albumin $20 \%$ infusion to increase albumin blood level in hypoalbuminemia dogs. Animals used in this study were 5 dogs whose results showed the levels of albumin below normal limits or hypoalbuminemia. Dogs with hypoalbuminemia will be infused with human serum albumin (HSA) $20 \%$ through intravenous for \pm 4 hours. Then, these dogs blood will be drawn days after infusion to screen for albumin levels. The results obtained in the form of examination data of albumin blood levels in the blood before and after infusion will be analyzed with paired T-test. The results showed an increase of albumin level significantly from an average of $1.98 \pm 0.356$ to $2.28 \pm 0.257(\mathrm{P}<0.05)$. This study shows the presence of human albumin serum through intravenous infusion was able to increase albumin levels in dogs with hypoalbuminemia.
\end{abstract}

Keywords: Dog; albumin; hipoalbuminemia; infusion; Human serum albumin 20\%

\begin{abstract}
Abstrak
Albumin terdiri dari 50\% total protein plasma dan merupakan protein utama yang sangat penting di dalam tubuh hewan. Hipoalbuminemia dapat terjadi akibat berbagai kondisi, seperti kehilangan protein nefropati, kehilangan protein enteropati, diare kronis dan akut atau perdarahan berat, serta kondisi malnutrisi dan malabsorbsi. Penelitian ini bertujuan untuk mengetahui pengaruh pemberian serum albumin manusia (SAM) 20\% intravena terhadap kadar albumin dalam darah anjing dengan status hipoalbuminemia. Hewan yang digunakan dalam penelitian ini adalah 5 ekor anjing yang hasil pemeriksaan kadar albuminnya menunjukkan di bawah batas normal atau hipoalbuminemia. Anjing dengan status hipoalbuminemia akan diberi SAM 20\% melalui infus intravena selama \pm 4 jam. Sehari setelah diterapi, dilakukan pengambilan darah untuk diperiksa kadar albumin. Hasil yang diperoleh berupa data pemeriksaan kadar albumin dalam darah sebelum dan sesudah diterapi dianalisis dengan T-tes berpasangan. Hasil analisis menunjukkan bahwa terjadi peningkatan kadar albumin secara signifikan dari rata-rata 1,98 $\pm 0,356$ menjadi 2,28 \pm $0,257(\mathrm{P}<0,05)$ setelah diterapi SAM 20\%. Penelitian ini menunjukkan bahwa pemberian SAM melalui infus intravena mampu meningkatkan kadar albumin pada anjing dengan status hipoalbuminemia.
\end{abstract}

Kata kunci: anjing; albumin; hipoalbuminemia; infus; serum albumin manusia 20\% 


\section{Pendahuluan}

Albumin dengan berat molekul (BM) \pm 69.000 $(69 \mathrm{kDa})$, menduduki $40-60 \%$ dari total protein (Gatta, 2012). Menurut Salasia dan Hariono (2010), albumin mempunyai fungsi penting dalam memelihara tekanan osmosis darah yaitu sebagai cadangan asam amino untuk protein jaringan dan nilai kadar albumin dapat turun karena hambatan sintesa albumin, break down albumin yang berlebihan akibat penyakit, dan peningkatan konsentrasi globulin. Nilai kadar albumin di bawah batas normal biasa dikenal dengan hipoalbuminemia. Hipoalbuminemia bisa terjadi akibat berbagai kondisi, seperti kehilangan protein nefropati, kehilangan protein enteropati, gangguan fungsi hati, perdarahan berat, kondisi malnutrisi dan malabsorbsi, diare kronis maupun akut, terbakar, ketidakseimbangan hormon, dan juga penyakit ginjal (proteinuria) (Kaslow, 2010).

Hipoalbuminemia pada penyakit kritis dapat menyebabkan retensi cairan, metabolisme obat yang tidak baik, penyembuhan yang buruk, peningkatan morbiditas, dan mortalitas pada manusia dan anjing. Penurunan konsentrasi albumin salah satunya disebabkan karena kerusakkan hepar yang menyebabkan penurunan sintesis albumin, selain itu karena amonia (umumnya meningkat dalam penyakit hepatik), serta konsentrasi albumin dan glukagon yang abnormal akan menghambat pelepasan albumin dari hepatosit (Tams, 2003). Latimer dkk. (2003) menambahkan bahwa kadar albumin juga akan mengalami penurunan drastis ketika hewan mengalami proteinuria yang disebabkan oleh penyakit pada ginjal, protein-losing enterophaty, penyakit kulit eksudatif, luka bakar, parasit internal, dan efusi protein yang tinggi. Menurut penelitian yang dilakukan oleh Ikenoue dkk., (2000), nilai kadar albumin tidak ditentukan oleh, umur, jenis kelamin, berat badan, dan ras.

Plasma beku segar adalah satu-satunya pengobatan hewan untuk hipoalbuminemia hingga sekitar pertengahan tahun 2000-an. Namun, pengobatan plasma sering tidak efisien dan mahal karena jumlah plasma yang dibutuhkan untuk menaikkan kadar serum albumin: $20-30 \mathrm{ml} / \mathrm{kg}$ untuk peningkatan konsentrasi albumin $0,5 \mathrm{~g} / \mathrm{dl}$ dan plasma beku segar juga dapat menyebabkan reaksi imunogenik (Mazzaferro, 2002). Produk albumin yang tersedia adalah canine-specific albumin, bovine serum albumin dan human serum albumin. Canine-specific albumin telah diuji pada 14 pasien anjing yang menderita septik peritonitis dengan kondisi hipoalbuminemia. Pemberian canine-specific albumin melalui intravena pada pasien anjing tidak menyebabkan reaksi yang merugikan dan dapat meningkatkan nilai albumin dan nilai tekanan osmotik koloid 2 jam setelah terapi dan bertahan sampai dengan 24 jam kemudian. Tidak ada reaksi tertunda merugikan yang dilaporkan oleh pemilik pasien anjing yang diberikan canine-specific albumin. Akan tetapi, canine-specific albumin tersedia dalam jumlah yang terbatas sehingga sulit untuk didapatkan (Craft dan Powell, 2012).

Produk bovine serum albumin sudah tersedia secara komersil. Namun penelitian yang dilakukan oleh Mosley dan Mathews (2005), melaporkan bahwa pemberian bovine serum albumin pada 10 pasien anjing telah menyebabkan perkembangan antibodi anti-albumin dan reaksi hipersensitivitas. Hasil penelitian tersebut menunjukkan bahwa penggunaan bovine serum albumin tidak cocok sebagai terapi untuk anjing. Masalah ketersediaan canine-specific albumin dan keamanan penggunaan bovine serum albumin pada pasien anjing tersebut menjadikan human serum albumin (serum albumin manusia) sebagai alternatif pengobatan untuk pasien anjing dengan kondisi hipoalbuminemia. Penggunaan serum albumin manusia (SAM) pada anjing telah banyak dilakukan 
Julitha Dewitri, et. al.

(Mazzaferro, 2002; Martin, 2004).

Serum albumin manusia dibuat dari plasma darah manusia yang diendapkan dengan alkohol (Uhing, 2004; Boldt, 2010). Penelitian yang dilakukan Mazzaferro (2002) menunjukkan bahwa penggunaan SAM dengan konsentrasi $25 \%$ secara efektif meningkatkan serum albumin, total protein, dan tekanan osmotik koloid pada anjing yang sakit kritis. Serum albumin manusia dapat membantu mengikat asam lemak bebas dan bermanfaat sebagai pengobatan tambahan untuk pasien dengan pankreatitis. Menurut Uhing (2004) dan Boldt (2010), SAM dapat digunakan untuk terapi hipoalbuminemia. Penggunaan SAM juga bisa untuk mendukung dalam pemberian obat dan pengiriman elektrolit di tempat-tempat peradangan. Serum albumin manusia dengan konsentrasi $25 \%$ juga telah dilaporkan berhasil digunakan pada beberapa anjing dengan hipovolemia, edema paru, ascites, kehilangan protein enteropati, dan kehilangan protein nefropati (Tilley, 2003). Tujuan dan manfaat dari penelitian ini adalah untuk melihat apakah pemberian SAM $20 \%$ dapat meningkatkan kadar albumin pada anjing dengan status hipoalbuminemia serta meningkatkan keberhasilan terapi.

\section{Materi dan Metode}

Penelitian dilakukan di Laboratorium Pratical Animal, Fakultas Kedokteran Hewan Universitas Gadjah Mada. Hewan penelitian yang di gunakan adalah 5 ekor anjing $(\mathrm{n}=5)$ dengan status hipoalbuminemia setelah dilakukan pemeriksaan kadar albumin dalam darah. Bahan yang diperlukan dalam penelitian ini adalah SAM 20\% (Human albumin 20\% Behring low salt ${ }^{\circledR}$ ) produk dari CSL Behring GmbH Marburg, Germany dan diimport oleh
PT Dexa Medica Palembang, Indonesia, darah berEDTA, Natrium Clorida $(\mathrm{NaCl})$ 0,9\% yang diproduksi oleh PT Braun Medical Indonesia yang digunakan sebagai pelarut SAM. Cairan desinfektan berupa alkohol 70\% (PT Jayamas Medica Industri, Indonesia), dan pakan anjing. Alat yang digunakan dalam penelitian ini meliputi kandang anjing dengan ukuran panjang $150 \mathrm{~cm}$ x lebar $110 \mathrm{~cm} \times$ tinggi $130 \mathrm{~cm}$, tempat pakan, gloves, tempat minum, selotip, gunting, dan timbangan. Alat yang digunakan dalam pengambilan sampel darah meliputi terumo syringe 3 cc, tourniquet, tabung Vaculab K3 EDTA (asam etilen diamin tetra asetat) produksi PT OneMed, Indonesia. Alat yang digunakan untuk terapi SAM Inflo intravena catheter 24g dan disposible infusion set. produksi PT. OneMed, Indonesia. Alat yang digunakan untuk pemeriksaan klinis meliputi termometer dan stetoskop.

Sampel darah dari 5 ekor anjing hewan penelitian diambil melalui vena cephalica sebanyak 1 $2 \mathrm{ml}$ dengan menggunakan spuit $3 \mathrm{ml}$. Darah dimasukkan ke dalam tabung ber-EDTA untuk pemeriksaan kadar albumin. Pengukuran kadar albumin plasma diuji di laboratorium Sadewa Yogyakarta menggunakan metode bromcresol green (BCG) dengan alat microlab 300. Prinsip uji ini yaitu serum ditambahkan pereaksi albumin akan berubah warna menjadi hijau, kemudian diperiksa pada spektrofotometer. Intensitas warna hijau ini menunjukan kadar albumin pada serum. Jika tandatanda klinis dan hasil darah menunjukkan kondisi hipoalbuminemia maka akan dilanjutkan dengan pemberian SAM 20\%. Perhitungan volume pemberian serum albumin manusia diturunkan dari penelitian Hackner(2012):

$10 \mathrm{x}$ [ kadar albumin yang diharapkan - kadar albumin pasien] x BB (kg) x 0,35 
Volume albumin yang diberikan tidak boleh melebihi $1,25 \mathrm{~g} / \mathrm{kg}$. Produk albumin yang dipakai dalam penelitian ini adalah Human Albumin Behring, low salt $20 \%{ }^{\circledR}$ yaitu dalam $100 \mathrm{ml}$ mengandung $19,2 \mathrm{~g}$ Albumin. Volume SAM selanjutnya akan diencerkan dengan larutan infus natrium klorida $(\mathrm{NaCl})$ 0,9\% dengan perbandingan $1: 9(1 \mathrm{SAM}: 9 \mathrm{NaCl})$ dan ditransfusi melalui infus intravena selama kurang lebih 4 jam. Frekuensi tetesan infus yang lebih lambat dapat menurunkan prevalensi dan tingkat keparahan reaksi dari SAM (Hackner, 2012). Sehari setelah diterapi, dilakukan pengambilan sampel darah kembali untuk diperiksa kadar albumin pasca terapi. Pengaruh pemberian serum albumin manusia terhadap kadar albumin dalam darah pada anjing penderita hipoalbuminemia dianalisis menggunakkan T-tes berpasangan pada program SPSS.

\section{Hasil dan Pembahasan}

Data terkait 5 sampel anjing yang digunakan dalam penelitian ini dan hasil pemeriksaan kadar albumin dalam darah anjing sebelum dan sesudah terapi serum albumin manusia disajikan dalam Tabel 1.

Tabel 1. Data 5 sampel anjing hipoalbuminemia dan pemeriksaan kadar albumin dalam darah sebelum dan sesudah diinfus SAM $20 \%$.

\begin{tabular}{|c|c|c|c|c|c|}
\hline \multirow[t]{2}{*}{ Nomor } & \multirow[t]{2}{*}{ Nama Hewan } & \multicolumn{3}{|c|}{ Kadar Albumin dalam Darah (g/dl) } & \multirow{2}{*}{$\begin{array}{l}\text { Nilai Normal albumin pada } \\
\text { anjing } \\
(\mathrm{g} / \mathrm{dl})\end{array}$} \\
\hline & & Sebelum & $\begin{array}{l}\text { Peningkatan } \\
\text { albumin }\end{array}$ & Sesudah & \\
\hline 1 & Nori (Betina) & 1,4 & 0,5 & 1,9 & \\
\hline 2 & Molly(Betina) & 2,3 & 0,3 & 2,6 & \\
\hline 3 & Chiko (Jantan) & 2,1 & 0,2 & 2,3 & $2,3-4,1^{*}$ \\
\hline 4 & Putih (Betina) & 2,2 & 0,2 & 2,4 & \\
\hline 5 & Pogan(Betina) & 1,9 & 0,3 & 2,23 & \\
\hline Rata-rata & & $1,98 \pm 0,356^{*}$ & 0,3 & $2,28 \pm 0,257^{*}$ & \\
\hline
\end{tabular}

Tabel 1 menunjukkan adanya peningkatan rata-rata nilai kadar albumin dari 1,98 $\mathrm{g} / \mathrm{dl}$ menjadi $2,28 \mathrm{~g} / \mathrm{dl}$ setelah diterapi SAM $20 \%$ dan rata-rata peningkatan nilai albumin sebesar $0,3 \mathrm{~g} / \mathrm{dl}$. Hasil analisis menggunakan T-tes berpasangan mendapatkan nilai signifikansi sebesar $0,005(\mathrm{P}<0,05)$. Nilai tersebut menyatakan bahwa terjadi peningkatan kadar albumin yang signifikan dalam darah pada 5 ekor sampel anjing dengan status hipoalbuminemia sebelum dan sesudah diterapi SAM $20 \%$. Hasil diatas selaras dengan penelitian oleh Throop et al. (2004), yang menyatakan bahwa terapi koloid dapat membantu meningkatkan motilitas dan absorpsi gastrointestinal pada hewan dengan hipoalbuminemia sedang sampai parah. Pemberian koloid dapat menjaga tekanan osmotik koloid dan mengurangi akumulasi cairan ekstravaskular. Koloid sintetis dan alami yang tersedia untuk veteriner antara lain Hexastarch 6\%, Dextran 70 6\%, Human albumin 25\%, Human albumin 12,5\%, Human albumin 5\%, Oxyglobin, dan Canine fresh-frozen plasma. Pemberian SAM pada pasien hewan yang mengalami kondisi hipoalbuminemia menurut Call (2005), dapat meningkatkan kadar albumin, protein total, dan tekanan osmotik. Data peningkatan kadar albumin pada 5 sampel anjing disajikan pada Gambar 2. 


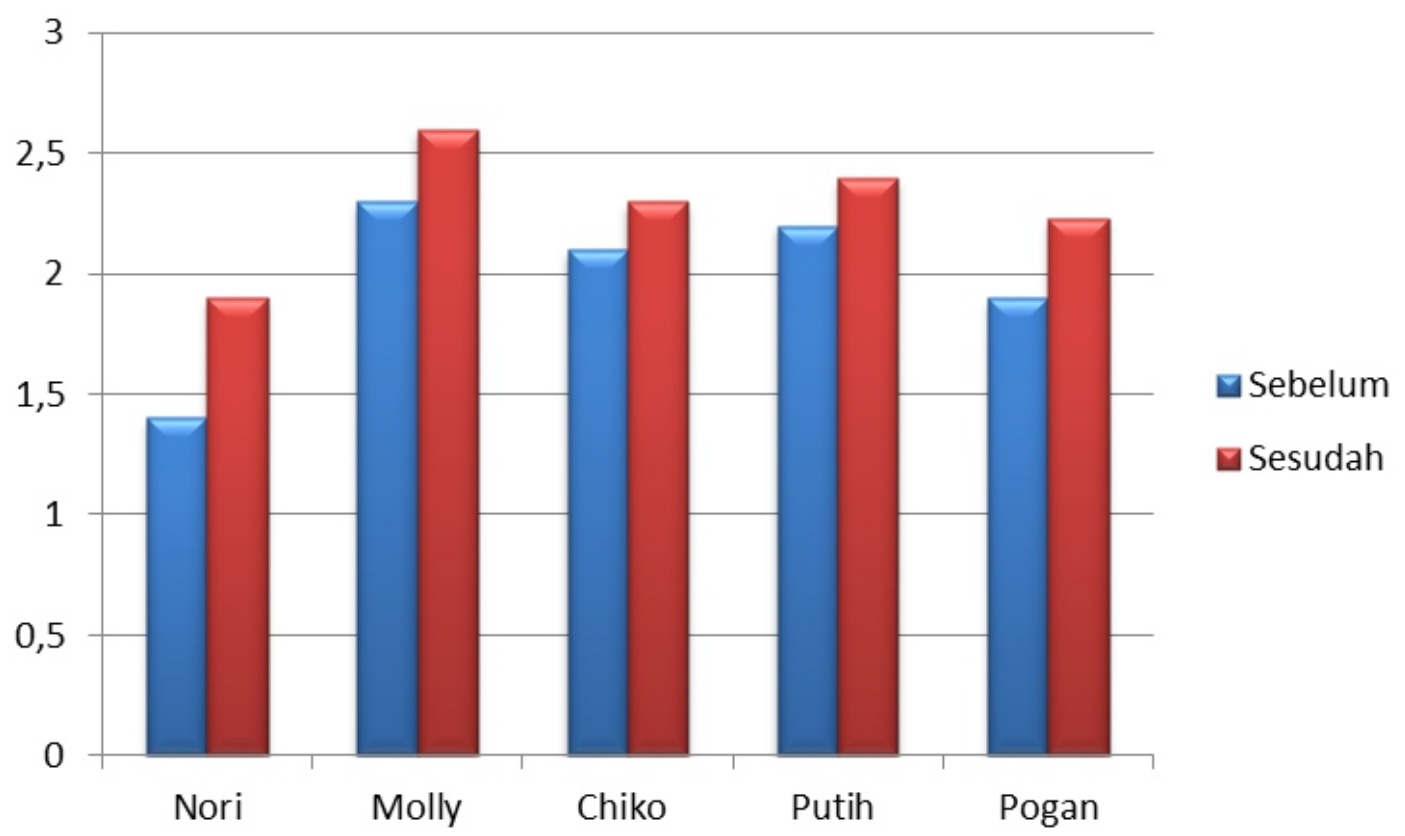

Gambar 2. Hasil pemeriksaan kadar albumin dalam darah sebelum dan sesudah diterapi serum albumin manusia $20 \%$

Gambar 2 menunjukkan terjadinya peningkatan nilai kadar albumin dalam darah pada semua sampel anjing dengan status hipoalbuminemia setelah diinfus dengan serum albumin manusia $20 \%$. Hasil penelitian ini selaras dengan penelitian retrospektif yang dilakukan oleh Matthews (2008), di Ontario Veterinary College pada 64 ekor anjing sakit yang telah menerima infus SAM $25 \%$ dengan laju konstan 0,1-1,7 m1/ kg/jam selama $\pm 4-72$ jam dari Juni 1997 hingga Desember 2001. Penelitian tersebut mendapatkan hasil 47 ekor anjing (71\%) menjadi sehat dan dipulangkan 2-13 hari setelah terapi, 11 ekor anjing (16\%) dieutanasia, dan 8 ekor anjing (12\%) mati selama 18 jam terapi SAM $25 \%$. Uji statistik pada penelitian tersebut menunjukkan bahwa penggunaan serum albumim manusia 25\% dapat meningkatkan nilai albumin secara signifikan $(\mathrm{P}<0,0001)$.

Albumin adalah protein serbaguna dengan antioksidan, imunomodulator, detoksifikasi, dan sebagai pembawa obat. Albumin dapat berperan sebagai protein eksogen atau endogen untuk pengobatan berbagai penyakit, sistem pengiriman obat berbasis albumin meliputi nanopartikel albumin-obat, protein fusi albumin, pro-obat, dan turunan peptida yang mengikat secara kovalen ke albumin. Selama beberapa tahun terakhir, penggunaan SAM menjadi perdebatan yang berfokus pada apakah albumin dapat bertindak sebagai pembawa obat yang lebih baik untuk pengiriman molekul makro atau tidak (Fasano et al., 2005). Serum albumin manusia memiliki kapasitas untuk mengikat beragam molekul, hal ini dimungkinkan karena muatan negatif SAM memfasilitasi pengikatan elektrostatik berbagai ligan dengan albumin, yang bertindak sebagai depot dan pembawa untuk banyak senyawa obat (Lejon et al., 2004).

Serum albumin manusia merupakan protein plasma yang paling banyak di tubuh manusia yang berperan penting dalam transportasi dan metabolisme senyawa endogen dan eksogen (Gerasimova,et al., 2008). Pasien dengan gagal jantung atau penyakit 
Pengaruh Pemberian Serum Albumin Manusia terhadap Kadar Albumin dalam Darah pada Anjing dengan status Hipoalbuminemia

lainnya di mana ada volume intravaskular yang berlebihan tidak akan mendapatkan keuntungan dari penggunaannya. Serum albumin manusia tidak boleh digunakan dalam upaya untuk meningkatkan tekanan darah pada pasien normovolemik dan tidak efektif sebagai nutrisi intravena (Call, 2005). Menurut Peterson dan Talcott (2013), SAM termasuk dalam larutan koloid yang dapat digunakan untuk terapi hipovolemia, inflamasi, serta meningkatkan tekanan onkotik koloid pada pasien hipoalbuminemia. Kondisi hipoalbuminemia dapat mempengaruhi keberhasilan suatu terapi. Ikatan albumin-obat merupakan faktor yang harus diperhatikan sehubungan dengan nilai distribusi obat, karena ikatan ini dapat mempengaruhi jumlah fraksi obat bebas yang mampu melakukan penetrasi ke jaringan atau organ (Wijayanti dan Dwi, 2017) Kondisi dari 5 ekor sampel anjing dengan status hipoalbuminemia mengalami peningkatan setelah terapi SAM 20\%. Peningkatan nilai albumin terjadi secara bervariasi pada ke 5 ekor sampel anjing, salah satu faktor yang mempengaruhi adalah kondisi fisik dan klinis yang berbeda pada setiap sampel. Berdasarkan hasil penelitian, SAM 20\% dapat diaplikasikan sebagai terapi suportif untuk mengatasi kondisi hipoalbuminemia. Penelitian lanjutan terkait efek samping setelah pemberian infusi SAM 20\% sangat disarankan untuk mengetahui efek samping tertunda dari pemberian SAM 20\% sehingga dapat dilakukan penanganan lanjutan.

\section{Kesimpulan}

Berdasarkan hasil penelitian, SAM 20\% dapat diaplikasikan sebagai terapi suportif untuk mengatasi kondisi hipoalbuminemia. Pemberian infusi SAM $20 \%$ dapat meningkatkan kadar albumin dalam darah pada anjing yang menderita hipoalbuminemia.

\section{Ucapan Terima kasih}

Ucapan terima kasih disampaikan kepada Departemen Farmakologi Fakultas Kedokteran Hewan Universitas Gadjah Mada dan Kementrian Riset dan Teknologi Republik Indonesia yang telah memberikan dana melalui Hibah Penelitian Unggulan Perguruan Tinggi (PUPT) tahun 2017.

\section{Daftar Pustaka}

Boldt, J. (2010). Use of albumin: an update. British journal of anaesthesia.104(3):276-84.

Call, D. (2005). The Use of Human Albumin Serum in Dogs. www. VetFolio.com. Internal medicine. Vol. 26 No. 12. Tanggal akses 1 november 2017.

Craft, E.M. dan Powell, L. L. 2012. The use of caninespesific albumin in dogs with septic peritonitis. Veterinary emergency and critical care, 22: 631-639.

Fasano M, Curry S, Terreno E, Galliano M, Fanali G, Narciso P, et al. (2005). The extraordinary ligand binding properties of human serum albumin. IUBMB Life; 57: 787-796.

Gatta, A., Verardo, A. \& Bolognesi, M. (2012). 'Hipoalbuminemia', Internal and Emergency Medicine, Vol. 7, no. 3, pp. 193-199

Gerasimova, Y. V., Erchenko, I. A., Shakirov, M. M., Godovikova, T. S. 2008. Interaction of Human Serum Albumin and its Clinically Relevant Modification with Oligoribonucleatides. Bioorganic and Medicinal Chemistry Letters 18: 4511-4514.

Hackner, G. S. (2012). Plasma And Albumin Transfusions: Indications And Controversies. Cornell University Veterinary Specialists.

Ikenoue, N., Saitsu, Y., Shimoda., Kokue, E. (2000). Disease-induced alteration in plasma drugbinding percentage in dogs. The Vet Quaterly.22:1-43-49.

Kaslow, J.E. (2010). Analysis od Serum Protein. Santa ANA ; 720 North Tustin Avenue Suite 104,CA.

Latimer, K.S.; Edward, A. M.; Keith, W.P. (2003). 
Julitha Dewitri, et. al.

Duncan and Prashe's Veterinary Laboratory Medicine: Clinical Phatology. US Iowa Press.

Lejon S, Frick IM, Björck L, Wikström M, Svensson S. (2004). Crystal structure and biological implications of a bacterial albumin binding module in complex with human serum albumin. JBiol Chem;279: 42924-42928.

Martin, L.(2004). Human Albumin Solutions In The Critical Patient. Iveccs Proc:274-278

Mathews, K. (2008). The Therapeutic Use of 25\% Human Serum Albumin in Critically Ill Dogs and Cats. Department of Clinical Studies, Emergency and Critical Care Medicine, Ontario Veterinary College, University of Guelph, Guelph, Ontario N1H 6H8, Canada

Mazzaferro EM, Rudloff E, Kirby R.(2002). The role of albumin replacement in the critically ill veterinary patient. J Vet Emerg Crit Care; 12:113-128.

Mosley, C.A.E. dan Mathews, K.A. 2005. The use of concentrated bovine serum albumin in canines (abstr). Vet Anesth Analg 32:14-15.

Peterson, M. E., dan Talcott, P. A. 2013. Small Animal Toxicology Third Edition. USA: Elsevier Saunders.
Salasia, S. I.O dan Hariono. Bambang. (2010). Patologi Klinik Veteriner Kasus Patologi Klinis. Yogyakarta: Samudra Biru. Hal. 6-7.

Tams, T. R. (2003). Handbook of small Animal Gastroenterology, $2^{\text {nd }}$ Edition. Saunders. Hal. 289.

Throop, J.L., Bingaman S, Huxley V. 2004. Differences between human and other mammalian albumins raises concerns over the use of human serum albumin in the dog. $\mathrm{J}$ Vet Intern Med;18(3):439

Tilley Lp, Smith Jr. Fwk. (2003). The 5-Minute Veterinary Consult: Canine And Feline, Ed 3. Philadelphia, Lippincott, Williams \& Wilkins.

Uhing, Michael R. (2004). The albumin controversy. Clinics In Perinatology.31: 475-488

Wijayanti AD, Dwi Cahyo BS. 2017. Hubungan Kadar Albumin dan Enrofloksasin dalam Plasma Anjing yang Diterapi Enrofloksasin. Acta Veterinaria Indonesiana. Vol. 5, No 1: 42-46. 